\title{
Frequency of extended spectrum beta lactamase in E.Coli and klebsiella pneumoniae in bacterial cultures.
}

1. MBBS, M.Phil (Microbiology) Assistant Professor Pathology Sahara Medical College Narowal.

2. MBBS, M.Phil (Microbiology) Demonstrator Pathology Sahara Medical College Narowal.

3. M.Phil (Microbiology)

Assistant Professor Pathology

Sahara Medical College Narowal.

\section{Correspondence Address:}

Dr. Saeeda Nabat ul Hassan

Department of Pathology

Sahara Medical College Narowal.

doctor.saeeda@gmail.com

Article received on:

22/09/2020

Accepted for publication:

$30 / 11 / 2020$

\begin{abstract}
Saeeda Nabat ul Hassan', Ghulam Asghar Bhutta², Khushbu Farva ${ }^{3}$
ABSTRACT... Objective: To determine frequency and pattern of extended spectrum beta lactamase in Klebsiella pneumoniae and E. coli in bacterial cultures. Study Design: Cross Sectional study. Setting: Department of Pathology Sahara Medical College Narowal. Period: January to June 2020. Material \& Methods: Total 1100 bacterial isolates were studied out of them $655 \mathrm{E}$.coli and 445 of klebsiella pneumoniae. All samples were subjected to double disc diffusion method using third generation cephalosporin and amoxacillin-clavulanic acid for detection of ESBL. Data was analyzed using SPSS software version 24, and results were calculated in the form of frequency, percentage and standard deviation. P-value $\leq 0.05$ was taken as statistically non-significant. Results: There were $48.9 \%$ male and $51.1 \%$ female subjects out of 1100 total cases. E.coli was detected in 59.5\% and klebsiella in $40.5 \%$ samples. Total $44.2 \%$ samples were positive for ESBL enzyme. Of 655 E.coli samples $40.8 \%$ and of 445 Klebsiella pneumoniae samples $49.2 \%$ were positive for ESBL enzyme. Conclusion: It is necessary to detect ESBL positive Klebsiella pneumoniae and E.coli in laboratory workflow to avoid unnecessary use of antibiotics and development of resistance against them.
\end{abstract}

Key words: $\quad$ Beta Lactamase, Bacterial Cultures, E.Coli, Klebsiella Pneumoniae.

Article Citation: Nabat ul Hassan S, Bhutta GS, Farva K. Frequency of extended spectrum beta lactamase in E.COLI and klebsiella pneumoniae in bacterial cultures. Professional Med J 2021; 28(9):1288-1291.

https://doi.org/10.29309/TPMJ/2021.28.09.6097

\section{INTRODUCTION}

Enterobacteriaceae are major cause of hospital acquired infections worldwide, of these E.coli and Klebsiella pneumoniae are GIT flora and main pathogens. ${ }^{1}$ The increased burden in hospitals especially with limited facilities, leads to hospital acquired infections ${ }^{2,3}$ Due to wide spread use of cephalosporins, its resistance has developed in our community. Enterobacteriaceae have developed different mechanisms of resistance and extended spectrum beta lactamases (ESBL) are the most important of them. There are 200 variants of ESBL including Temoria and Sulphydryl. ${ }^{4}$ These enzymes hydrolyze betalactam antibiotics and have increased spectrum of activity against antibiotics, therefore they are called extended spectrum, but these enzymes are inhibited by beta lactamase inhibitors like clavulanic acid, tazobactam and sulbactam. ${ }^{5}$ There are various factors determining rate of hospital acquired infections like severity of disease, type of antibiotics given and immunity status of the patient. Among patients having severe hospital acquired infections quick detection of ESBL producing bacteria and their prompt treatment can reduce morbidity. ${ }^{6}$ Purpose of our study was to find frequency of ESBL producing $\mathrm{K}$. pneumoniae and E.coli to reduce antibiotic resistance among patients and to minimize hospital stay.

\section{MATERIAL \& METHODS}

It was a cross sectional analytical study completed in the duration of six months from January to June 2020, after approval from ethical committee (114ERC-SMC). Study was conducted in pathology department of Sahara Medical College, Narowal. Total 1100 bacterial isolates were studied out of them 655 E.coli and 445 of Klebsiella pneumoniae. All isolates were subjected to double disc diffusion method using third generation cephalosporin and amoxacillinclavulanic acid for detection of ESBL. Under aseptic measures a turbid suspension of bacterial 
isolates was prepared in normal saline equivalent to 0.5 McFarland and standard. A swab was immersed in the solution and extra solution removed by squeezing on inner side of vial then it was inoculated to the full plate of Mueller Hinton agar $(150 \mathrm{~mm})$. Plate was rotated 360 degree four times to ensure uniform bacterial lawn. Discs containing antibiotics of cefpodoxime $10 \mathrm{mcg}$, aztreonem $30 \mathrm{mcg}$ and cefotaxime $30 \mathrm{mcg}$ were placed in the agar plate using sterilized forcep. Four discs were used to increase chances of ESBL detection. At $35 \pm 2$ degree Celsius these plates were incubated for $16-18$ hours according to recommendations of CLSI. Size of inhibitory zones were measured in millimeter using ruler. All bacterial isolates showing inhibitory zones were

suspected of ESBL producer and Double Disc Synergy Test was performed on them. Data was analyzed using SPSS software version 24 , and results were calculated in the form of frequency, percentage and standard deviation. P-value $\leq 0.05$ was taken as statistically non-significant.

\section{RESULTS}

Total 1100 isolates were studied including (48.9\%) male and $(59.1 \%)$ female cases. E.coli was detected in 655(59.5\%) and klebsiella in $445(40.5 \%)$ samples. Total $44.2 \%$ samples were positive for ESBL enzyme. Of 655 E.coli samples $267(40.8 \%)$, of 445 Klebsiella pneumoniae samples 219(49.2\%) were positive for ESBL enzyme.

\begin{tabular}{|c|c|c|c|c|c|c|c|c|c|c|c|c|}
\hline \multirow[t]{2}{*}{ Age } & \multirow[t]{2}{*}{ Frequency } & \multicolumn{2}{|c|}{ Sex } & \multicolumn{4}{|c|}{ Specimen } & \multicolumn{5}{|c|}{ Unit } \\
\hline & & Male & Female & Pus & Urine & Blood & Sputum & $\begin{array}{l}\text { Surgical } \\
\& \text { Allied }\end{array}$ & $\begin{array}{l}\text { Medical } \\
\text { \& Allied }\end{array}$ & Pediatrics & $\begin{array}{l}\text { Obs \& } \\
\text { Gynae }\end{array}$ & $\begin{array}{c}\text { Out- } \\
\text { Patients }\end{array}$ \\
\hline$<10$ & 85 & 50 & 35 & 31 & 29 & 18 & 7 & 20 & 12 & 35 & 5 & 13 \\
\hline $11-20$ & 141 & 86 & 55 & 72 & 31 & 27 & 11 & 49 & 28 & 32 & 14 & 18 \\
\hline $21-30$ & 293 & 110 & 183 & 154 & 40 & 90 & 9 & 103 & 97 & 33 & 40 & 20 \\
\hline $31-40$ & 314 & 143 & 171 & 86 & 92 & 124 & 12 & 114 & 105 & 35 & 38 & 22 \\
\hline $41-50$ & 146 & 90 & 56 & 73 & 38 & 30 & 5 & 55 & 31 & 28 & 20 & 12 \\
\hline$>50$ & 121 & 59 & 62 & 51 & 27 & 37 & 6 & 42 & 29 & 25 & 15 & 10 \\
\hline Total & 1100 & $\begin{array}{c}538 \\
(48.9 \%)\end{array}$ & $\begin{array}{c}562 \\
(51.1 \%)\end{array}$ & $\begin{array}{c}467 \\
(42.5)\end{array}$ & $\begin{array}{c}257 \\
(23.4 \%)\end{array}$ & $\begin{array}{c}326 \\
(29.6 \%)\end{array}$ & 50 (4.5\%) & $\begin{array}{c}383 \\
(34.8 \%)\end{array}$ & $\begin{array}{c}302 \\
(27.5 \%)\end{array}$ & $\begin{array}{c}188 \\
(17.1 \%)\end{array}$ & $\begin{array}{c}132 \\
(12 \%)\end{array}$ & $95(8.6 \%)$ \\
\hline $\begin{array}{l}\text { ESBL } \\
\text { Total }\end{array}$ & 486 (44.2\%) & 235 & 251 & 186 & 118 & 150 & 22 & 139 & 97 & 86 & 112 & 52 \\
\hline
\end{tabular}

\begin{tabular}{|l|c|}
\hline Antibiotic Disc Content & Zone Break Point $(\mathbf{m m})$ \\
\hline Ceftazidime & $10 \mathrm{mcg}: \leq 22 \mathrm{~mm}$ \\
\hline Cefotaxime & $30 \mathrm{mcg}: \leq 22 \mathrm{~mm}$ \\
\hline Aztreonam & $30 \mathrm{mcg}: \leq 17 \mathrm{~mm}$ \\
\hline Cefpodoxime & $30 \mathrm{mcg}: \leq 17 \mathrm{~mm}$ \\
\hline
\end{tabular}

Table-II. Screening test for ESBL.

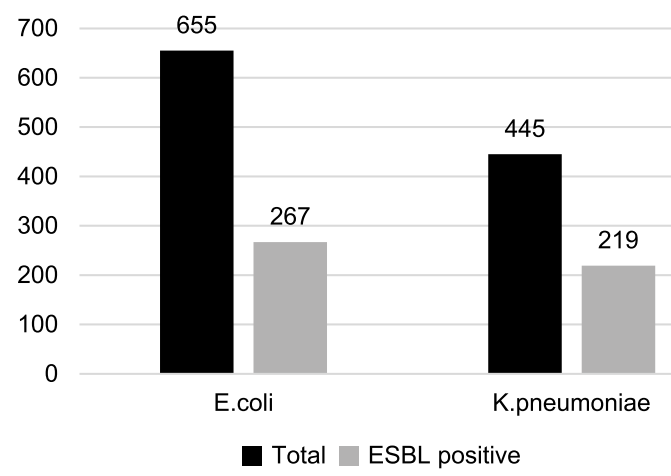

Figure-1. Frequency of ESBL positive out of total positive isolates of E.coli and K. pneumonia.

\section{DISCUSSION}

Enterobacteriaceae are common cause of hospital acquired infections. E.coli and K. pneumoniae are resistant to many groups of antibiotics including cephalosporin group and penicillin group. It is due to ESBL activity. Our study shows that ESBL producing $\mathrm{K}$. pneumoniae and E.coli reported from each unit in frequent samples of blood, urine, pus and sputum. In our study total 486 isolates were positive for ESBL including $267(54.9 \%)$ for E.coli and $219(45.1 \%)$ or K. pneumoniae Our results are similar to a study conducted in Sudan in which $36.7 \%$ isolates were positive for E.coli and K. pneumoniae out of which $34.2 \%$ were for E.coli and $40.1 \%$ for K.pnemoniae. ${ }^{7}$ In our the specimens included blood, pus, urine and sputum. ESBL was most frequent in the pus samples. Post-surgical wounds are usually prone to ESBL producing bacteria. Lack of proper sterilization 
of surgical instruments, not adhering to contact precautions and infection control measures may cause hospital acquired infections with these bacteria. ${ }^{8}$ Urinary catheters, intravenous lines and implants are easily colonized by ESBL producing E.coli and K. pneumoniae leading to serious urinary tract infections and septicemia. ${ }^{9}$ There are various methods for detecting ESBL producing pathogens like E.coli and K. pneumoniae but double disc diffusion method is usually used in routine laboratory work because it is a simple method easy to perform, easy to interpreted and cost effective as well. ${ }^{10}$ If $\mathrm{K}$. pneumoniae and E.coli are found to be resistant against any one of cephalosporins, they should be tested for producing ESBL enzyme and double disc synergy test should be performed on them. ${ }^{11}$ In our hospitals mostly patients are treated empirically by extensive use of cephalosporins, without determining culture and sensitivity, hence increasing frequency of ESBL producing bacteria and increasing antibiotic resistance. Frequency of ESBL producing bacteria is increasing in community as well. According to a study $63.4 \%$ E.coli and $60.7 \%$ K. pneumoniae were ESBL positive and mortality rate was higher due to ESBL positive bacteria as compared to ESBL negative bacteria. They reported higher mortality in patients using Beta lactams and beta lactamase inhibitors than those using carbapenems. ${ }^{12}$ With increasing frequency of ESBL positive bacteria broad spectrum antibiotics are being used extensively hence increasing resistance against them especially carbapenems. So alternative antibiotics are required to treat such infections. According to a study piperacillin-tazobactam can be used alternatively in some infections but not widely recommended. ${ }^{13,14}$ A study reported ESBL maximum resistance against ampicillin (100\%) followed by cephalosporins as $94.12 \%$ resistant against cefuroxime, $61.76 \%$ resistant for ceftriaxone. ${ }^{15}$

\section{CONCLUSION}

Extended spectrum beta lactamases were found more frequently in bacterial cultures taken from our tertiary care hospital, so targeted antibiotic therapy after culture sensitivity can be more effective, reducing morbidity and hospital stay and may prevent antibiotic resistance in our community as well.

Copyright $@ 30$ Nov, 2020.

\section{REFERENCES}

1. Rafique A, Rasheed F, Saeed M, Hassan S, Nadeem SF, Imran AA. Epidemiology of extended spectrum beta lactamase producing gram negative rods. Journal of Liaquat University of Medical \& Health Sciences. 2019 Jul 17; 18(02):164-8.

2. Habib MB, Akbar NS. Frequency and susceptibility pattern of extended spectrum beta lactamase producing aerobic gram negative bacteria in postoperative infections. Nano Biomed. Eng. 2019 Apr 1; 11(2):138-49.

3. Rocha FR, Fehlberg LC, Cordeiro-Moura JR, Ramos AC, Pinto VD, Barbosa FC. High frequency of extendedspectrum beta-lactamase-producing klebsiella pneumoniae nosocomial strains isolated from a Teaching Hospital in Brazil. Microbial Drug Resistance. 2019 Jul 1; 25(6):909-14. https://doi.org/10.1089/ mdr.2018.0142.

4. Rahim MA, Samad T, Mitra P, Zaman S, Habib SH, Afroze SR, Haque WM, Uddin KN. Frequency, risk factors and antibiotic sensitivity pattern of extendedspectrum beta-lactamase producing escherichia coli and klebsiella pneumoniae causing urinary tract infection: Experience from a Tertiary Care Hospital of Bangladesh. BIRDEM Medical Journal. 2017 May 4; 7(2):155-9. https://doi.org/10.3329/birdem.v7i2.32455.

5. Weinstein MP, Lewis JS. The clinical and laboratory standards institute subcommittee on antimicrobial susceptibility testing: Background, organization, functions, and processes. Journal of clinical microbiology. 2020 Feb 24; 58(3).

6. Karigoudar RM, Karigoudar MH, Wavare SM, Mangalgi SS. Detection of biofilm among uropathogenic Escherichia coli and its correlation with antibiotic resistance pattern. Journal of laboratory physicians. 2019Jan; 11(1):17. https://dx.doi.org/10.4103\%2FJLP. JLP_98_18.

7. Ahmed MA, Nuraldeen MA, Hitham M, Saeed AS, Ahmed MA. Extended-spectrum beta-lactamase-producing escherichia coli and klebsiella pneumoniae clinical isolates in sudanese hospitals: Analytical comparative cross sectional study. http://hdl.handle. net/123456789/613. 
8. Walther B, Klein KS, Barton AK, Semmler T, Huber C, Wolf SA, Tedin K, Merle R, Mitrach F, Guenther $S$, Lübke-Becker A. Extended-spectrum betalactamase (ESBL)-producing Escherichia coli and Acinetobacter baumannii among horses entering a veterinary teaching hospital: The contemporary" Trojan Horse". PloS one. 2018 Jan 30; 13(1):e0191873. https://doi.org/10.1371/journal.pone.0191873.

9. Toner L, Papa N, Aliyu SH, Dev H, Lawrentschuk N, Al-Hayek S. Extended-spectrum beta-lactamaseproducing Enterobacteriaceae in hospital urinary tract infections: Incidence and antibiotic susceptibility profile over 9 years. World journal of urology. $2016 \mathrm{Jul}$ 1; 34(7):1031-7. https://doi.org/10.1007/s00345-0151718-x

10. Iqbal R, Ikram N, Shoaib M, Muhammad JA, Raja TM, Abid AN, Aanam A, Bushra I, Faiza N. Phenotypic cofirmatory disc diffusion test (PCDDT), double disc synergy test (DDST), E-test OS diagnostic tool for detection of extended spectrum beta lactamase (ESBL) producing Uropathogens. J Appl Biotechnol Bioeng. 2017; 3(3):344-9.

11. Clinical and Laboratory Standards Institute (CLSI). Performance standards for antimicrobial susceptibility testing: Twentieth informational supplement, M100-S20. Vol. 30. Wayne, PA:CLSI, 2010:1-153.
12. Ray S, Anand D, Purwar S, Samanta A, Upadhye KV, Gupta P, Dhar D. Association of high mortality with extended-spectrum $\beta$-lactamase (ESBL) positive cultures in community acquired infections. Journal of Critical Care. 2018 Apr 1; 44:255-60. https://doi. org/10.1016/j.jcrc. 2017.10.036.

13. D'Angelo RG, Johnson JK, Bork JT, Heil EL. Treatment options for extended-spectrum beta-lactamase (ESBL) and AmpC-producing bacteria. Expert opinion on pharmacotherapy. 2016 May 2; 17(7):953-67. https:// doi.org/10.1517/14656566. 2016.1154538.

14. Schuetz AN, Reyes S, Tamma PD. Point-Counterpoint: Piperacillin-tazobactam should be used to treat infections with extended-spectrum-beta-lactamasepositive organisms. Journal of clinical microbiology. 2018 Mar 1; 56(3).

15. Oli AN, Eze DE, Gugu TH, Ezeobi I, Maduagwu UN, Ihekwereme CP. Multi-antibiotic resistant extendedspectrum beta-lactamase producing bacteria pose a challenge to the effective treatment of wound and skin infections. The Pan African Medical Journal. 2017; 27. https://doi.org/10.11604/pamj. 2017.27.66.10226.

\begin{tabular}{|c|c|c|c|}
\hline \multicolumn{4}{|c|}{ AUTHORSHIP AND CONTRIBUTION DECLARATION } \\
\hline Sr. \# & Author(s) Full Name & Contribution to the paper & Author(s) Signature \\
\hline 1 & Saeeda Nabat ul Hassan & $\begin{array}{l}\text { Topic selection and data } \\
\text { collection, Abstract and } \\
\text { recording. }\end{array}$ & Sacedr. \\
\hline 2 & Ghulam Asghar Bhutta & $\begin{array}{l}\text { Data analysis, Data } \\
\text { collection, Found additional } \\
\text { literature for information, Data } \\
\text { composing }\end{array}$ & Asplus? \\
\hline 3 & Khushbu Farva & $\begin{array}{l}\text { Data analysis, Data } \\
\text { collection. }\end{array}$ & Whustesente \\
\hline
\end{tabular}

